ZOOLOGIA 32 (6): 476-484, December 2015

http://dx.doi.org/10.1590/S1984-46702015000600007

\title{
The non-indigenous bryozoan Triphyllozoon (Cheilostomata: Phidoloporidae) in the Atlantic: morphology and dispersion on the Brazilian coast
}

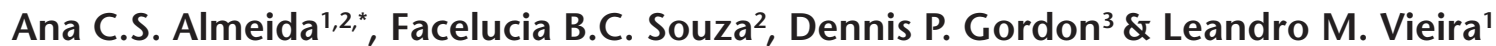

'Laboratório de Estudos de Bryozoa, Departamento de Zoologia, Centro de Ciências Biológicas, Universidade Federal de Pernambuco. 50670-810 Recife, PE, Brazil.

${ }^{2}$ Museu de Zoologia, Universidade Federal da Bahia. 40170-290 Salvador, BA, Brazil.

${ }^{3}$ National Institute of Water and Atmospheric Research. Private Bag 14901, Kilbirnie, Wellington, New Zealand.

*Corresponding author. E-mail: carol.salmeida@gmail.com

\begin{abstract}
Bryozoans constitute an important component of marine-fouling communities of anthropogenic substrata. Many species have been reported as exotic or widespread around the world, typically in ports and harbors of non-polar regions. Here we present the first record of a species of the bryozoan Triphyllozoon in the Atlantic Ocean. Triphyllozoon arcuatum (MacGillivray, 1889), described originally from Australia, is reported herein from natural substrata in Singapore and natural and artificial substrata in Brazil. Although easily recognizable, the species has not been previously reported from anywhere else in the Atlantic. In the latter instance, the species was collected during monitoring of the invasive scleractinian corals Tubastraea spp. on an oil platform originally from Singapore and now located at Todos os Santos Bay, northeastern Brazil. Colonies of $T$. arcuatum were also found associated with three species of sponges, giving evidence that it is also growing in the natural environment. Todos os Santos Bay is characterized by intense commercial shipping traffic and oil exploration and the finding of $T$. arcuatum on an oil platform provides strong evidence that it represents a non-indigenous species in the Atlantic. Owing to the possible impact of $T$. arcuatum in Brazil, further studies and monitoring of its bioinvasion are recommended.
\end{abstract}

KEY WORDS. Bioinvasion; Brazil; Bryozoa; invasive species; oil platform.

Marine bioinvasions have increased significantly during the last 40 years (McCann et al. 2007, IgnaCio et al. 2010). This is in part a consequence of anthropogenic transport of species to areas beyond their native habitats and natural home ranges, mainly by ballast water and fouling of hulls of ships and oceanic platforms (Marins et al. 2010, BumbeER \& Rocha 2012). Shipping activities are recognized as the main source of species' introductions in marine habitats (MACKIE et al. 2006, IGNACIO et al. 2010, BumbeER \& Rocha 2012), and in the Atlantic, the number of non-indigenous marine fouling species is increasing, especially in ports and harbors (MCCANN et al. 2007, Marins et al. 2010).

Among the fouling fauna, bryozoans are colonial sessile animals that live attached to any type of natural and artificial substrata and constitute an important component of such assemblages (Gordon \& MaWATARi 1992, McCann et al. 2007), sometimes with higher species diversity than other encrusting organisms (MARQUES et al. 2013). These animals have a suite of traits (e.g., fast-growing, tolerance of different substrata) that make them relatively adaptable to large scale disturbances and therefore likely to invade and become established in non-native habitats (Gordon \& MAWATARI 1992, MCCANn et al. 2007). Some species have long been recognized as invasive, being reported worldwide, such as the common marine-fouling Bugula neritina (Linnaeus, 1758) and Amathia verticillata (Delle Chiaje, 1831) (Mackie et al. 2006, Farrapeira 2011, Waeschenbach et al. 2015), among others.

The phidoloporid bryozoan genus Triphyllozoon Canu \& Bassler, 1917 is one of several genera that form erect lace-like colonies and are popularly referred to as 'lace bryozoans'. These colonies show different degrees of architectural complexity, and may be calyciform, or scrolled, or widely open (e.g., HARMER 1934, HAYWARD 1999, 2000, 2004) and, since many of them may also be highly colored, they can be quite conspicuous. Triphyllozoon species are commonly associated with living substrata like corals, hydrozoans and algae (GORDON 1989, O'HARA 2001, Puce et al. 2007, Winston 1986) as well as rock and suitable artificial substrata (Bоск 1982). 
Phidoloporidae is a large family, comprising 22 genera and 324 species in all oceans (Hayward 2004, Bock \& Gordon 2013), but the greatest diversity is found in the Coral Triangle (CANU \& BASSLER 1929, HaRmER 1934), the wider tropical Southwest Pacific (e.g., Tilbrook 2006), and the seas around Australia (HAYWARD 1999, 2000, 2004). Triphyllozoon comprises 32 species, having a tropical to temperate distribution in the Indian and Western Pacific Oceans (Harmer 1934, Hayward $1999,2000,2004)$, with a single species reported from the Red Sea (Aмui \& Kaselowski 2006). Some 16 genera and 60 phidoloporid species occur in the Atlantic Ocean, of which at least 15 species are found in Brazilian waters, but the vast majority of these are encrusting species of the genera Fodinella Tilbrook, Hayward \& Gordon, 2001, Plesiocleidochasma Soule, Soule \& Chaney, 1991, Rhynchozoon Hincks, 1895, Schizotheca Hincks, 1877 and Stephanollona Duvergier, 1920 (VIEIRA et al. 2008, Winston \& Vieira 2013, Winston et al. 2014). Recent studies, however, have shown that the full diversity of bryozoans from the Brazilian coast is yet to be described (e.g., Almeida \& Souza 2014, Ramalho et al. 2011, Vieira et al. 2010) and species of Phidoloporidae continue to be discovered (e.g., Winston \& Vieira 2013, Winston et al. 2014).

Recently, colonies of a species of Triphyllozoon were collected in northeastern Brazil. Although easily recognizable, it has not been previously reported from either Brazil (VIEIRA et al. 2008) or anywhere else in the Atlantic (Воск 2015) and we are confident that this finding represents the first record of the genus in the Atlantic Ocean.

In this paper we present the first record of Triphyllozoon arcuatum (MacGillivray, 1889) from Brazil, describing and comparing specimens from this locality and from Singapore. Also we discuss the supposed introduction of the species in the Atlantic.

\section{MATERIAL AND METHODS}

Specimens were collected from Ituberá and Todos os Santos Bay (TSB), in the state of Bahia, Brazil. Additional specimens were collected at the Industrial Port Complex of Suape (CIPS), in the state of Pernambuco, Brazil (sent by Farrapeira CMR, Lira SMA and Ferreira GFA) (Fig. 1). Colonies from Brazil were first examined under a stereomicroscope and selected portions were mounted on stubs and coated with gold for examination by scanning electron microscopy (JEOL JSM-6390LV and JSM-6460LV). Measurements were made from digital SEM images using the software Image ${ }^{\circledR}$. Specimens are lodged in the Bryozoa collection of Museu de Zoologia at Universidade Federal da Bahia (UFBA) and Universidade Federal de Pernambuco (UFPE).

Material from Singapore (no precise locality), illustrated here using a Hitachi TM3000 SEM, comprises a part of a larger colony in the collection of the Raffles Museum of Biodiversity Research (RMBR) and is lodged at NIWA Invertebrate Collection, Wellington.

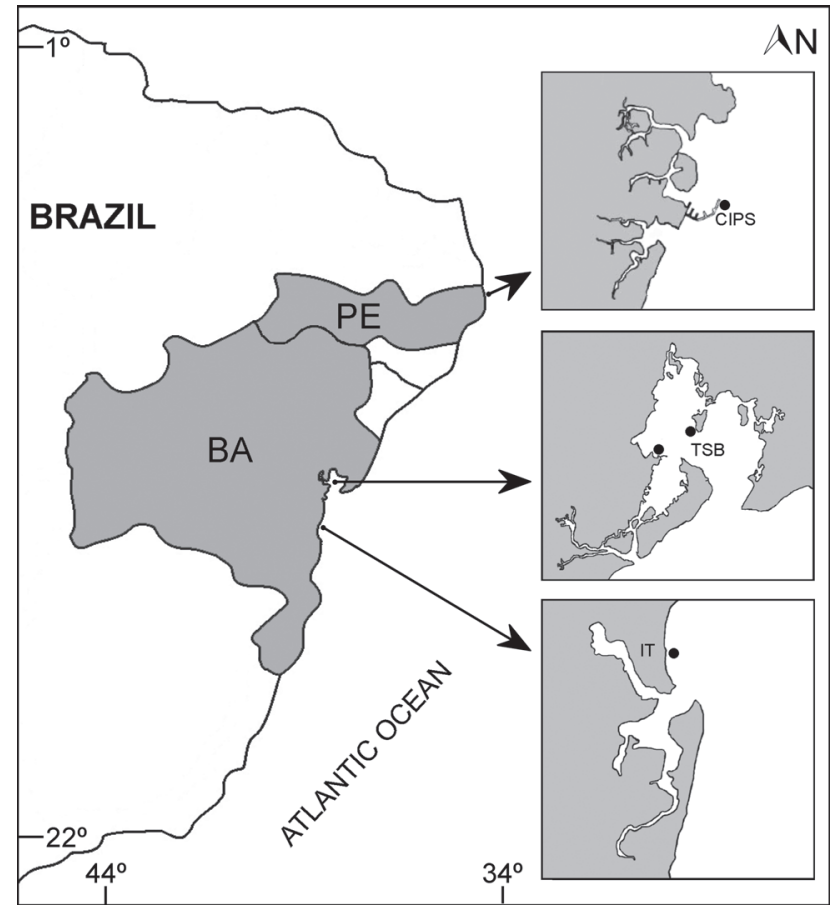

Figure 1. Distribution map of Triphyllozoon arcuatum in Brazilian coast. Legends: PE, Pernambuco State; BA, Bahia State; CIPS, Industrial Port Complex of Suape; TSB, Todos os Santos Bay; IT, Ituberá.

\section{TAXONOMY}

\section{Triphyllozoon arcuatum (MacGillivray, 1889)}

Figs. 2-17

Retepora monilifera form arcuata MacGillivray, 1889: 29 [South Australia].

Triphyllozoon arcuatum (MacGillivray, 1889): Hayward, 1999: 14, figs. $6 \mathrm{~d}, 9$ [Northern Territory and northeastern Western Australia].

Description. Colony robust, thickly calcified, attached to the substratum by a broad stalk. Growing edges irregularly frilled and anastomosing, forming open lobed cups of variable diameter (Figs. 2-7). Fenestrulae small, oval, ca. 0.33-0.42 mm diameter; trabeculae larger than fenestrulae, about 0.31-0.50 mm wide, comprising 2-3 alternating longitudinal zooid series that face toward colony interior (Fig. 8). Autozooids at growing edges elongate, longer than wide; frontal shield smooth, with 1-2 small marginal pores, bordered by thin raised sutures (Fig. 9). Primary orifice slightly wider than long, somewhat Dshaped; distal rim with irregular beading (small crenulations), condyles long, narrow, asymmetrical, obscured by proximal peristome. Oral spines $2-4$, present in early astogeny, laterally placed; all stout, hollow, basally jointed. Peristome low, developed as asymmetrical pair of lateral lobes, jointed, delimited 

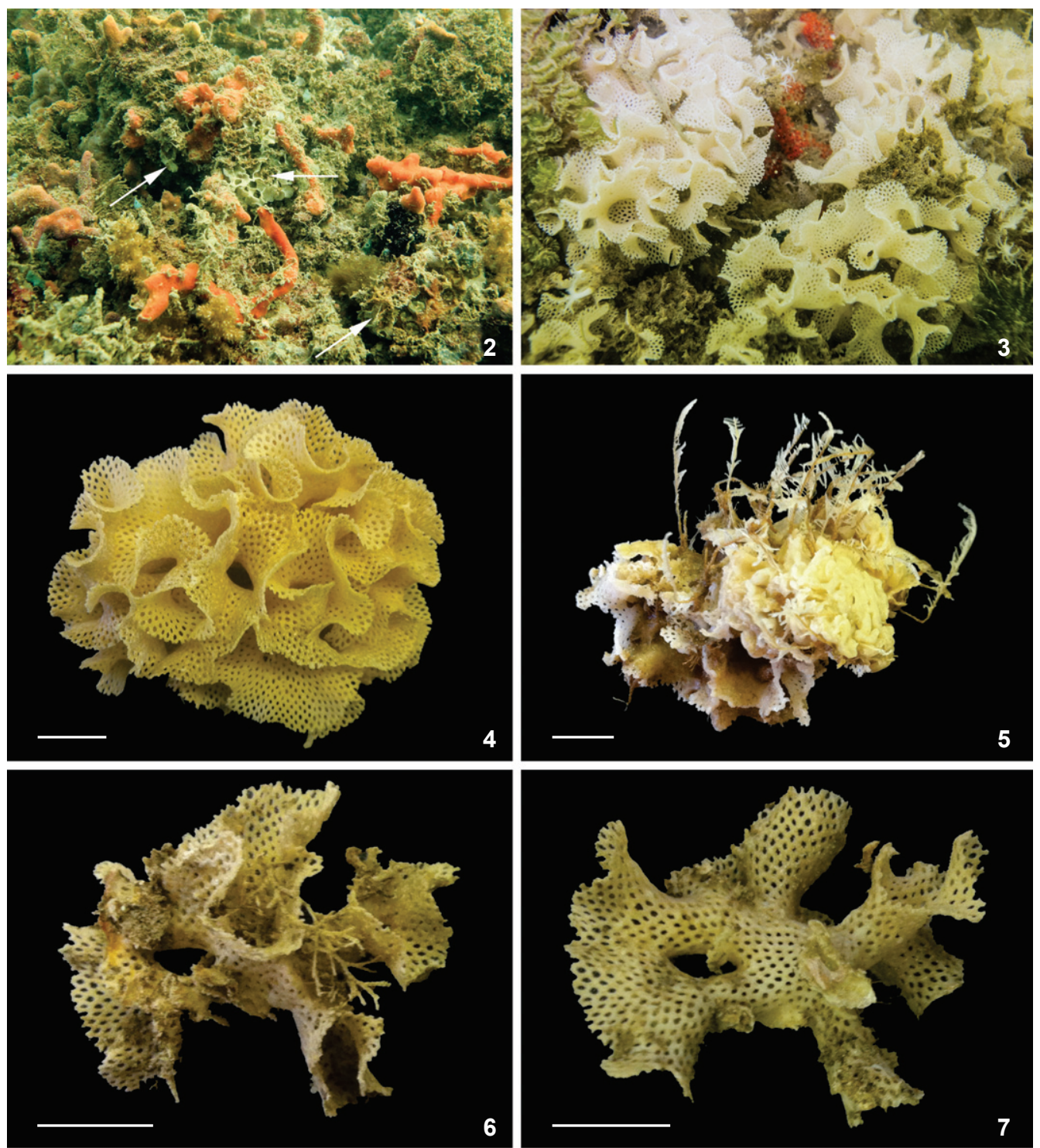

Figures 2-7. Triphyllozoon arcuatum. 2. Colonies associated with other encrusting organisms in natural environment at Todos os Santos Bay, Bahia, Brazil; 3. Close-up of colonies in natural environment at Todos os Santos Bay, Bahia, Brazil. Photos: Ricardo J. Miranda; 4. UFBA 560, Todos os Santos Bay, Bahia, Brazil, found attached to an oil platform; 5. UFBA 559, Ituberá, Brazil, associated with the sponges Tedania ignis and Clathrina sp. 6-7. UFBA 729. 6. Frontal view of the colony; 7. Abfrontal view of the colony showing broad stalk used to attachment at the sponge Dysidea etheria. Scale bars: $1 \mathrm{~cm}$.

by lateral, rounded pseudospiramen (labial pore). Each autozooid typically with a more or less transversely set peristomial avicularium, mandible triangular, distal margin serrated, acute to frontal plane, the crossbar complete (Figs. 12, 15). Frontal adventitious avicularia with two different morphologies: small and round, as long as wide, distal margin serrated and proximal margin smooth, complete crossbar, lacking columella; larger and oval, longer than wide, with smooth distal and proximal rims; complete crossbar, lacking columella. Large columnar avicularia placed at distal end of some fenestrulae, distal margin spatulate, proximal margin straight, with oval opesia and complete crossbar (Figs. 11, 17). Ooecium wider than long, prominent, more or less smooth or with weak surface texture, with a short, broad incurved labellum that barely descends into the peristome; suture weakly and variably trifoliate, broad, with prominent cross-connections; lateral sutures 

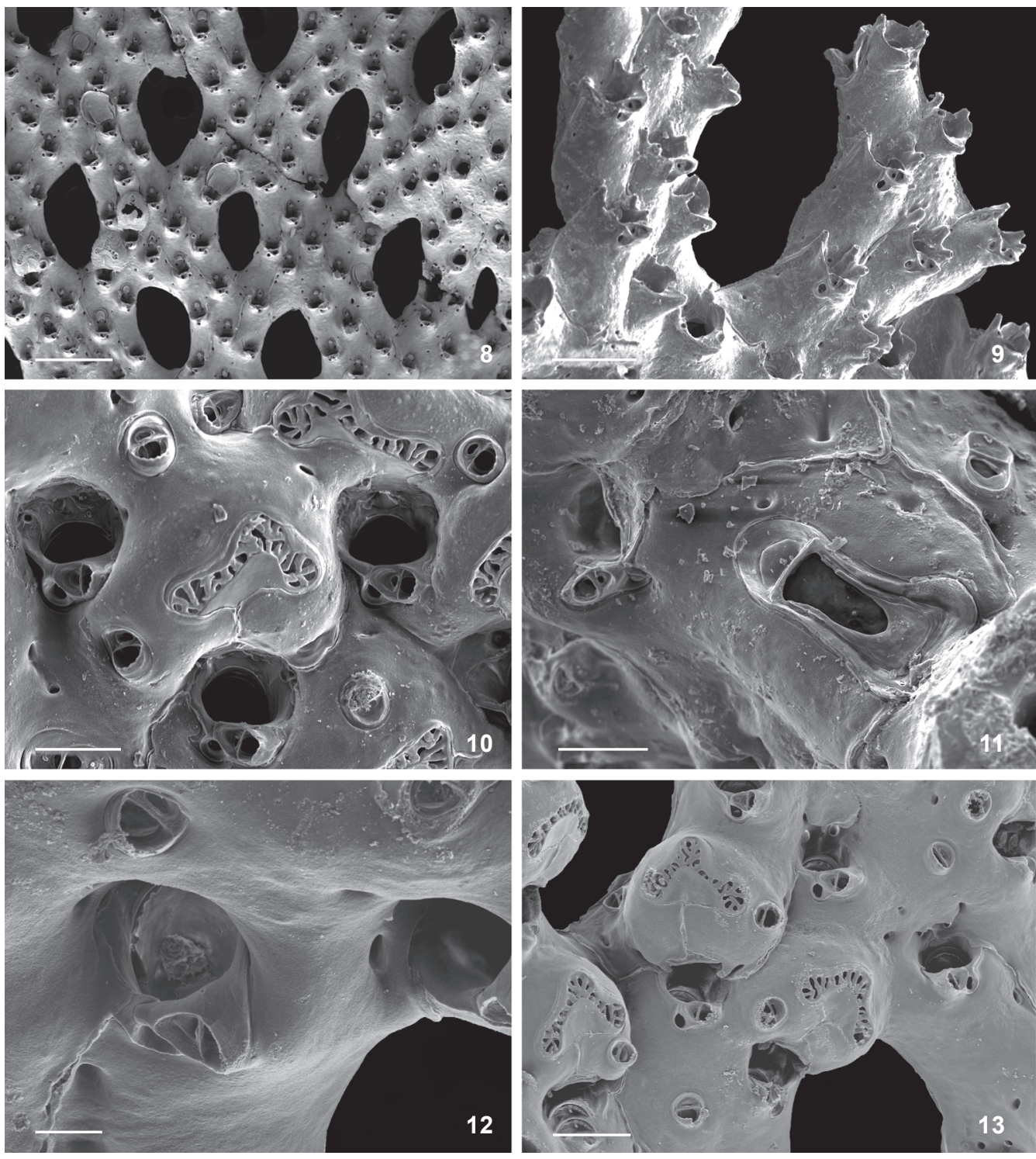

Figures 8-13. Triphyllozoon arcuatum. 8-11. UFBA 560, Todos os Santos Bay, Bahia, Brazil. 8. General aspect of the colony showing fenestrulae and trabeculae; 9. Autozooids in early ontogeny; 10. Close-up of ovicelled zooid, primary orifice, suboral and frontal avicularium; 11. Close-up of large columnar avicularium, suboral and frontal avicularia. 12-13. Specimens from Industrial Port Complex of Suape, Pernambuco, Brazil. 12. Close-up of primary orifice, condyles and suboral avicularium; 13. Ovicelled zooids and autozooid. Scale bars: $8=500 \mu \mathrm{m} ; 9=200 \mu \mathrm{m} ; 10,11=100 \mu \mathrm{m} ; 12=40 \mu \mathrm{m} ; 13=120 \mu \mathrm{m}$.

longer than the longitudinal suture, which may sometimes be almost lacking and the suture arcuate or boomerang-shaped (Figs. 10, 13-14). With increasing calcification ooecium becomes immersed and may partially obliterate the frontal sutures (Fig. 14). Abfrontal surface of colony somewhat granular, with distinct vibices; avicularia numerous, having almost exclusively the same morphology as the longer oval frontal avicularia, mostly surrounding fenestrulae adjacent to vibices (Figs. 16-17).
Material examined. BraziL, Bahia: Todos os Santos Bay (oil platform, $12^{\circ} 47^{\prime} \mathrm{S} 38^{\circ} 06^{\prime} \mathrm{W}, 10 \mathrm{~m}$ ), April 2014, LABPORUFBA leg., UFBA 560; Todos os Santos Bay (oil platform, $12^{\circ} 95^{\prime}$ S, $38^{\circ} 58^{\prime} \mathrm{W}, 25$ m), July 2014, LAMEB-UFBA leg., UFBA 740; Ituberá (sponge reefs, $13^{\circ} 45^{\prime} \mathrm{S} 38^{\circ} 53^{\prime} \mathrm{W}, 14 \mathrm{~m}$ ), October 2007, Cláudio Sampaio leg., UFBA 559; Ituberá (sponge, reefs, $13^{\circ} 45^{\prime} \mathrm{S}$ $38^{\circ} 45^{\prime} W$ ), October 2007, Cláudio Sampaio leg., UFBA 729; Brazil, Bahia: Todos os Santos Bay, Ilha dos Frades (coral reef, 

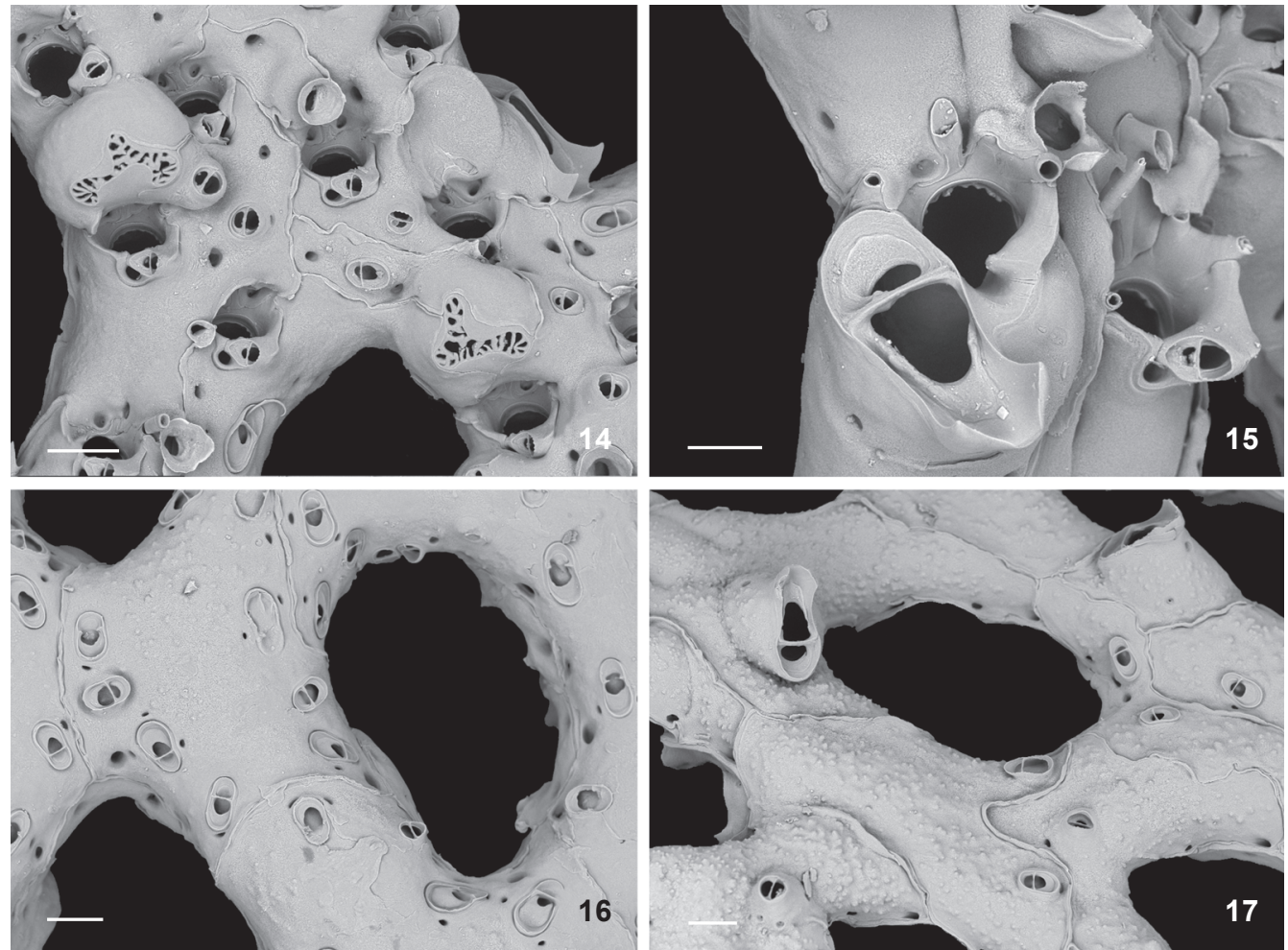

Figures 14-17. Triphyllozoon arcuatum, NIWA 98177, Singapore. 14. Ovicelled zooids and autozooids; 15. Close-up of primary orifice and avicularia; 16. Abfrontal surface of the colony; 17. Large columnar avicularia. Scale bars: $200 \mu \mathrm{m}$.

$\left.12^{\circ} 49^{\prime} \mathrm{S}, 38^{\circ} 39^{\prime} \mathrm{W}, 5 \mathrm{~m}\right)$, June 2015, Ricardo J. Miranda leg., UFBA 1415; Pernambuco: Suape Port (rope and pier columns), Cristiane M.R. Farrapeira, Simone M.A. Lira and Gledson F.A. Ferreira leg., UFPE 098. SingAPORE: Raffles Museum of Biodiversity Research leg., NIWA 98177.

Remarks. Triphyllozoon arcuatum was originally described from South Australia by MacGillivray (1889), with no precise locality indicated. HAYWARD (1999) re-examined the type material in the South Australian Museum and also examined specimens that he attributed to the same species from "Medil Beach, Darwin, WA", which seems to be an error for Mindil Beach, Darwin [Northern Territory (NT), not Western Australia] and also from "Holothuria Bank, NT" [Holothuria Banks are found off the coast of northeastern Western Australia]. Most likely this species from Singapore (where it is common) is the one illustrated by Ria Tan on the Wild Singapore website (http://www.wildsingapore.com/ wildfacts/bryozoa/bryozoan.htm). Recently the species was recorded from Straits of Johor, also at Singapore (ТіцвRоoк \& GoRDON 2015).

HAYWARD (1999) considered the distinctively sutured ovicell as a diagnostic character. In fact, the variable shape of the sutures - from arcuate to trifoliate with a short distal limb - has been observed by us in the specimens from Brazil and Singapore and this variation agrees with T. arcuatum from Australia (HAY-
WARD 1999). Although HAYWARD (1999) described the ooecium of T. arcuatum as lacking a labellum, a short and broad labellum is shown in one of his figures (HAYWARD 1999: p. 232, fig. 9c), as in specimens from Brazil and Singapore. One other highly distinctive feature of T. arcuatum is the transverse arrangement of the very short labial suture and pore and adjacent avicularium within the proximal peristome. This is probably the most immediately useful diagnostic character. HAYWARD (1999) described the distal orificial rim of T. arcuatum as "coarsely denticulate," which is consistent with our material. Other features such as 2-4 oral spines and three kinds of avicularia (round, oval and larger spatulate) are all consistent, although it is unclear what HAYWARD meant by a "domed' larger avicularium with a "broad, semi-elliptical mandible," unless he meant the broken avicularium illustrated in his fig. 9b. He did, however, note that the larger avicularium may be columnar (seen by us on the abfrontal side of the colony), but this aspect depends on the degree of secondary calcification, which can bury the column. This larger avicularium typically has a bicuspid distal rostral rim but the cusps can be rounded or lost by erosion or abrasion. These morphological characteristics in the large avicularia are variable in the same colony and are not here considered diagnostic of the species.

MacGillivray (1889) noted that colonies of T. arcuatum are formed by tubular units, but the material studied by him 
was poorly preserved, consisting of fragments. HAYWARD (1999) described the colony architecture of the species as unknown. We were able to analyze four entire colonies (UFBA 559, UFBA 560 , UFBA 729, UFBA 740) formed by open lobed cups of variable diameters (Figs. 2-7).

Species of Triphyllozoon are commonly found in association with other benthic organisms that serve as a substratum for bryozoan colonies: Triphyllozoon hirsutum (Busk, 1884), Triphyllozoon philippinense (Busk, 1884) and Triphyllozoon tricuspidatum (Harmer, 1933) were attached to coral (WINSTON 1986) and Triphyllozoon munitum (Hincks, 1878) was fixed to algae (O'HARA 2001). Triphyllozoon species have been collected from exposed rock faces and jetty pilings in Australia (Bock 1982). Specimens of T. arcuatum collected at TSB (northeast Brazil) were found attached to an oil platform and associated with the sponges Tedania ignis (Duchassaing \& Michelotti, 1864) and Clathrina sp. (Fig. 5); colonies from Ituberá were attached to the demosponge Dysidea etheria (de Laubenfels, 1936) (Figs. 6-7). Thus, this is the first record of a Triphyllozoon species that uses sponges as a substratum. Colonies from Pernambuco (CIPS) were collected on artificial substrata (rope and pier columns).

\section{DISCUSSION}

Until now T. arcuatum was known in the literature only from South Australia and Northern Territory and Singapore, in the Indo-Pacific (Hayward 1999, Tilbrook \& Gordon 2015). Here we present the first description of T. arcuatum since HAYWARD (1999), based on specimens from Singapore and Brazil. Regarding the occurrences in tropical northern Australia and Singapore, a distributional range that includes South Australia is unusual but not impossible, comprising the Indo-West Pacific marine biogeographic region. The discovery of the same species in the South Atlantic, however, is noteworthy. Notwithstanding, species of Triphyllozoon have never been found in the Atlantic Ocean before, and the specimens here analyzed were mostly associated with anthropogenic structures in areas of considerable maritime activity, appropriate to the first step in habitat colonization by an exotic species (Tyrell \& Byers 2007, Bumbeer \& Rocha 2012).

We analyzed the occurrence of $T$. arcuatum in Brazilian waters based on the ten criteria for the recognition of marine introduced species proposed by CHAPMAN \& CARLTON (1991). The majority of these criteria can be easily applied to T. arcuatum in Brazil. The genus was not previously found either in Brazil or the Atlantic (VIEIRA et al. 2008, Bоск 2015) despite the easy recognition of colonies (Criterion 1 - Previously Unknown in Local region). Also it was only previously recorded in the IndoPacific from Australia (MacGillivray 1889), leading us to conclude that the occurrence of the species in the Atlantic represents an unusual natural distribution (Criterion 7 - Disjunct Global Distribution). Despite the unknown larval type of $T$. arcuatum, all phidoloporid species are expected to have non-feeding and short-lived lecithotrophic coronate larvae (WANNINGER et al. 2005) that have limited dispersal capability. Thus, dispersal during larval stage is insufficient to explain the present distribution of T. arcuatum in the Atlantic Ocean (Criteria 8 - Insufficient Dispersal Capabilities). There are also no evolutionary affinities between $T$. arcuatum and other species of the family since Triphyllozoon has been widely reported only in the Indian and Pacific Oceans (Criterion 10 - Exotic Evolutionary Origin).

It is important to note that colonies from Brazil were collected at three distinct areas with commercial shipping traffic and petroleum activities (in accordance with Criterion 3 - Human Mechanism of Introduction) that may increase the likelihood of introduction of exotic species (MARINS et al. 2010, SAMPAIO et al. 2012). In the state of Pernambuco, colonies of T. arcuatum were collected at the Industrial Port Complex of Suape (CIPS). This complex is important due to its location as part of commercial routes from Europe and the United States, making it the principal distribution port in northeastern Brazil (ReIs et al. 2011). Ituberá in the southern portion of the state of Bahia lies adjacent to the Camamu-Almada Basin, a region with increasing oil exploration that hosts 12 blocks of oil and derivatives exploration (Hatje et al. 2008, Paixão et al. 2011). Todos os Santos Bay (TSB) hosts the Port of Salvador, which is intensely occupied by humans and is a site of industrial activities related to petroleum refining (Alves et al. 2006, BARROS et al. 2012).

In concordance with Criterion 4 (Association with Known Introduction) other non-indigenous marine species have been recorded at the Brazilian localities where T. arcuatum has been found. At CIPS the copepod Temora turbinata Dana, 1849 and the bivalve Isognomon bicolor (C. B. Adams, 1854) (DiAs et al. 2013, SiLvA et al. 2014) were registered as non-indigenous. At TSB, the swimming-crab Charybdis hellerii (A. MilneEdwards, 1867), the ascidians Ascidia tapuni Monniot \& Monniot, 1987 and Cnemidocarpa irene (Hartmeyer, 1906) and the orange cup corals Tubastraea coccinea Lesson, 1829 and T. tagusensis Wells, 1982, were recognized as exotic (Almeida \& Coelho 2008, Rocha et al. 2012, Sampaio et al. 2012). In all cases the species originated from the Indo-Pacific, as does T. arcuatum. Interestingly, at TSB, specimens of T. arcuatum were collected more than once during monitoring of the invasive Tubastraea spp. (C. Menegola and R.J. Miranda, personal observation). The monitoring was developed at an oil platform that came from Singapore in 1998 and remained at Arraial do Cabo, Rio de Janeiro, for six months before moving to Bacia de Campos, also in Rio de Janeiro, where it stayed until 2014 (Coutinho 2014). The platform is now located at Canteiro de São Roque (TSB), Bahia (Coutinho 2014), a site mainly destined to the construction of platforms. Recently, specimens of T. arcuatum were collected at Ilha dos Frades, also at TSB, a new occurrence since previous investigations at this site did not collect any Triphyllozoon colony (R.J. Miranda, personal observation). This occurrence can be taken as evidence that the species is spread- 
ing along the TSB and that it was introduced into TSB via ships servicing oil platforms, as already suggested for orange cup corals (de Paula \& Creed 2004, Sampaio et al. 2012 Silva et al. 2014). Specimens from other localities on the Brazilian coast Ituberá and CIPS - have been collected since 2007, prior to those found on the oil platform in TSB (collected in 2014). Additional study is required to determine if T. arcuatum also occurs in Rio de Janeiro, the current distribution of the species in natural substrates of Rio de Janeiro and Pernambuco, and also to understand to which extent the species is established on the Brazilian coast. Finally, the occurrence of T. arcuatum attached to artificial substrata satisfies Criterion 5 (Prevalence on or Restriction to New or Artificial Environments).

Bryozoans are also some of the commonest fouling species of ports and harbors around the world (RYLAND 1965, GoRdon \& Mawatari 1992, Marques et al. 2013). Ships have been vectors of many introductions of different taxonomic groups (Carlton \& Geller 1993, Ignacio et al. 2010, Rocha et al. 2012) and the fouling ability was proved to affect the global range of bryozoan species, mainly transported by hulls of ships (WaTTs et al. 1998). The ability to foul artificial structures was observed in Triphyllozoon species by Воск (1982) and by the discovery of colonies from Brazil attached to an oil platform and rope and pier columns. Importantly, colonies of T. arcuatum were also found associated with sponges and were ovicelled, giving evidence that it is also growing and reproducing in the natural environment.

At least eight bryozoan species have been reported as nonindigenous in Brazilian waters - Hippopodina viriosa Tilbrook, 1999, Licornia diadema (Busk, 1852), Licornia jolloisii (Audouin, 1826), Membraniporopsis tubigera (Osburn, 1940), Schizoporella errata (Waters, 1878), Amathia verticillata (Delle Chiaje, 1822), Virididentula dentata (Lamouroux, 1816) (it may represent, however, a complex of cryptic species rather than a single widespread species, Fehlauer-Ale et al. 2015) and Watersipora subtorquata (d'Orbigny, 1852) (Farrapeira 2011, Vieira et al. 2013, 2014, Vieira \& Migotтo 2014). Rосна et al. (2013), however, listed 15 species as cryptogenic, and it is probable that this number reflects an insufficient effort to get to know the bryozoan fauna, especially in the northeast (VIEIRA et al. 2008), limiting the ability to detect new arrivals, as it has been the case with ascidians (RоснA et al. 2012). Owing to the potential ecological impact of T. arcuatum on coastal community structure and function, as already noted for Tubastrea spp. (Silva et al. 2014), further study regarding this bioinvasion in Brazil is recommended.

\section{ACKNOWLEDGMENTS}

This study is part of A.C.S. Almeida's PhD thesis supported by CAPES (Coordenação de Aperfeiçoamento de Pessoal de Nível Superior) through the Graduate Program in Animal Biology (Programa de Pós-Graduação em Biologia Animal) of the Departamento de Zoologia, UFPE. We are grateful to Carla Menegola (Laboratório de Biologia de Porifera e Fauna Associada,
UFBA), Marlene Peso-Aguiar (Laboratório de Malacologia e Ecologia Bentônica, UFBA), Anaíra Lage (Museu Nacional da Universidade Federal do Rio de Janeiro, UFRJ), Ricardo J. Miranda (Laboratório de Ecologia Bentônica, UFBA) and Ulisses Pinheiro (Laboratório de Porifera) for specimen collection and logistical support. Thanks to Cristiane M.R. Farrapeira, Simone M.A. Lira and Gledson F.A. Ferreira, who sent specimens from Pernambuco for comparison. We thank Julio Fernandez and Cristiana Castello-Branco (Laboratório de Taxonomia de Porifera, UFRJ) for sponges identification. We also thank Centro de Pesquisa Gonçalo Moniz (FIOCRUZ/BA) for SEM images. Dennis Gordon is grateful to Serena Teo and Tan S. Hee, National University of Singapore, for the opportunity to examine Singaporean Bryozoa. This study was funded by CNPq (474605/2013-2).

\section{LITERATURE CITED}

Almeida AO, Coelho PA (2008) Estuarine and marine brachyuran crabs (Crustacea: Decapoda) from Bahia, Brazil: checklist and zoogeographical considerations. Latin American Journal of Aquatic Research 36(2): 183-222. doi: 10.3856/ vol36-issue2-fulltext-4

Almeida AC, Souza FBC (2014) Two new species of cheilostome bryozoans from the South Atlantic Ocean. Zootaxa 3753(3): 283-290. doi: 10.11646/zootaxa.3753.3.7

Alves OFS, Muene D, Dominguez JML (2006) Carbonate contents of bottom sediments of Todos os Santos Bay, Bahia, Brazil: their importance for biodiversity. Journal of Coastal Research Special Issue 39: 1671-1675.

Amui AM, Kaselowski J (2006) Bryozoa from the Gulf of Aden and the Red Sea. Part I: collections from the fifth expedition of the R.V. Meteor. Fauna of Arabia 22: 7-22.

Barros F, Costa PC, Cruz I, Mariano DlS, Miranda RJ (2012) Habitats Bentônicos na Baía de Todos os Santos. Revista Virtual de Química 4(5): 551-565.

Bоск PE (1982) Bryozoans (Phylum Bryozoa), p. 319-394. In: Shepherd SA, Thomas IM (Eds.) Marine Invertebrates of Southern Australia Part 1. Adelaide, South Australian Government.

Воск PE (2015) Genus Triphyllozoon. In: Bоск PE (Ed.) The Bryozoa Home Page. Available online at: http://bryozoa.net/ cheilostomata/phidoloporidae/triphyllozoon.html [Accessed: 20/02/2015]

Bock PE, Gordon DP (2013) Phylum Bryozoa Ehrenberg, 1831. Zootaxa 3703(1): 67-74. doi: 10.11646/zootaxa.3703.1.14

Bumbeer JA, Rocha RM (2012) Detection of introduced sessile species on the near shore continental shelf in southern Brazil. Zoologia 29(2): 126-134. doi: 10.1590/S1984-46702012000200005

CANU F, BASsLer RS (1929) Bryozoa of the Philippine region. United States National Museum Bulletin 100: 1-685.

Carlton JT, Geller JB (1993) Ecological roulette: the global transport of nonindigenous marine organisms. Science 261: 78-82. doi: 10.1016/0006-3207(94)90635-1 
Chapman JW, Carlton JT (1991) A test of criteria for introduced species: The global invasion by the isopod Synidotea laevidorsalis (Miers, 1881). Journal of Crustacean Biology 11(3): 386-400.

Coutinho R (2014) Parecer Técnico sobre o deslocamento da Plataforma P-27 para a Enseada de Paraguaçu (BTS). Available online at http://www.pdf-archive.com/2014/04/ 09/pt-ricardo-coutinho-petrobras [Accessed: 10/09/2014]

De Paula AF, Creed JC (2004) Two species of the coral Tubastrea (Cnidaria, Scleractina) in Brazil: a case of accidental introduction. Bulletin of Marine Science 74(1): 175-183.

Dias TLP, Mota ElS, Gondim AI, Oliveira JM, Rabelo EF, MendonÇa de Almeida S, Christoffersen ML (2013) Isognomon bicolor (C. B. Adams, 1845) (Mollusca: Bivalvia): First record of this invasive species for the States of Paraíba and Alagoas and new records for other localities of Northeastern Brazil. Check List 91: 157-161. doi: 10.15560/9.1.157

Farrapeira CMR (2011) The introduction of the bryozoan Zoobotryon verticillatum (Della Chiaje, 1822) in northeast of Brazil: a cause for concern. Biological Invasions 13: 13-16. doi: 10.1007/s10530-010-9788-6

Fehlauer-Ale KH, Winston Je, Tilbrook KJ, Nascimento KB, Vieira LM (2015) Identifying monophyletic groups within Bugula sensu lato (Bryozoa, Buguloidea). Zoologica Scripta 44: 334347. doi: 10.1111/zsc.12103

Gordon DP (1989) Bryozoans from coral reef-flat rubble Sa'aga, Western Samoa. New Zealand Journal of Zoology 16: 447463. doi: 10.1080/03014223.1989.10422912

Gordon DP, Mawatari SF (1992) Atlas of marine fouling Bryozoa of New Zealand ports and harbours. New Zealand Oceanographic Institute, Miscellaneous Publication 107: $1-52$.

Harmer SF (1934) The Polyzoa of the Siboga Expedition. Part 3. Cheilostomata Ascophora, I. Family Reteporidae. Siboga Expedition Reports 28: 502-640.

Hatje V, Barros F, Magalhães W, Riatto VB, Amorim FN, Figueiredo MB, Spanó S, Cirano M (2008) Trace metals and benthic macrofauna distributions in Camamu Bay, Brazil: sediment quality prior oil and gas exploration. Marine Pollution Bulletin 56: 348-379. doi: 10.1016/j.marpolbul.2007.10.029

Hayward PJ (1999) Taxonomic studies on some Australian Phidoloporidae (Bryozoa: Cheilostomatida). Journal of Zoology 249: 219-240. doi: 10.1111/j.1469-7998.1999.tb00760.x

Hayward PJ (2000) Lace corals (Bryozoa: Phidoloporidae) from Australia and the tropical south-west Pacific. Journal of Zoology 252: 109-136. doi: 10.1111/j.1469-7998.2000.tb00825.x

HaYward PJ (2004) Taxonomic studies on some Indo-West Pacific Phidoloporidae (Bryozoa: Cheilostomata). Systematics and Biodiversity 1(3): 305-326. doi: 10.1017/S1477200003001191

Ignacio BL, Julio LM, Junqueira AOR, Ferreira-Silva MAG (2010) Bioinvasion in a Brazilian bay: Filling gaps in the knowledge of Southwestern Atlantic biota. PLoS One 5(9): 1-9. doi: 10.1371/journal.pone.0013065
MacGillivray PH (1889) On some South Australian Polyzoa. Transactions of The Royal Society of South Australia 12: 24-30.

Mackie JA, Keough MJ, Christidis L (2006) Invasion pattern inferred from cytochrome oxidase I sequences in three bryozoans, Bugula neritina, Watersipora subtorquata, and Watersipora arcuata. Marine Biology 149: 285-295. doi: 10.1007/s00227-005-0196-X

McCann DL, Hitchcock NG, Winston JE, Ruiz GM (2007) Nonnative bryozoans in coastal embayments of the Southern United States: new records for the Western Atlantic. Bulletin of Marine Science 80(2): 319-342.

Marins FO, Novaes RML, Rocha RM, Junqueira AOR (2010) Non indigenous ascidians in port and natural environments in a tropical Brazilian bay. Zoologia 27(2): 213-221. doi: 10.1590/S1984-46702010000200009

Marques AC, Klôh AS, Migotto Ae, Cabral AC, Tigo APR, Bettim AL, Razzolini EL, Cascon HM, Bardi J, Kremer lP, Vieira LM, Bezerra LEA, Haddad MA, de Oliveira Filho RR, Gutierre SMM, Miranda TP, Franklin JR W, Rocha RM (2013) Rapid assessment survey for exotic benthic species in the São Sebastião Channel, Brazil. Latin American Journal of Aquatic Research 41: 265-285. doi: 10.3856/vol41-issue2-fulltext-6 O'Hara TD (2001) Consistency of faunal and floral assemblages within temperate subtidal rocky reef habitats. Marine \& Freshwater Research 52: 853-63. doi: 10.1071/MF00114

Paixão JF, de Oliveira OMC, Dominguez JML, Almeida ES, CarvaLHo GC, Magalhães WF (2011) Integrated assessment of mangrove sediments in the Camamu Bay (Bahia, Brazil). Ecotoxicology and Environmental Safety 74: 403-415. doi:10.1016/j.ecoenv.2010.10.038

Puce S, Bavestrello G, Di Camillo CG, Boero F (2007) Symbiotic relationships between hydroids and bryozoans. Symbiosis 44: 137-143.

Ramalho LV, Muricy G, Taylor PD (2011) Taxonomic revision of some lepraliomorph cheilostome bryozoans (Bryozoa: Lepraliomorpha) from Rio de Janeiro State, Brazil. Journal of Natural History 45: 767-798. doi: 10.1080/00222933. 2010.535917

Reis TNV, Guimarães-Barros NC, Vasconcelos ERTPP, Cocentino ALM, FujI MT (2011) Influence of the industrial port complex of Suape (Western Tropical Atlantic) on the biodiversity and biomass of Phaeophyceae. Tropical Oceanography 39(2): 142-154. doi: 10.5914/to.2011.0057

Rocha RM, Bonnet NYK, Baptista MS, Beltramin FS (2012) Introduced and native Phlebobranch and Stolidobranch solitary ascidians (Tunicata: Ascidiacea) around Salvador, Bahia, Brazil. Zoologia 29(1): 39-53. doi: 10.1590/S198446702012000100005

Rocha RM, Vieira LM, Migotto AE, Amaral ACZ, Ventura CRR, Pitombo FB, Santos KC, Simone LRL, Tavares M, Lopes RM, PiNheiro U, Marques AC (2013) The need of more rigorous assessments of marine species introductions: A counter 
example from the Brazilian coast. Marine Pollution Bulletin 67: 241-243. doi: 10.1016/j.marpolbul.2012.12.009

Ryland JS (1965) Polyzoa. Catalogue of Main Marine Fouling Organisms 2: 1-83.

Sampaio ClS, Miranda RJ, Maia-Nogueira R, Nunes JACC (2012) New occurrences of the nonindigenous orange cup corals Tubastraea coccinea and T. tagusensis (Scleractinia: Dendrophylliidae) in Southwestern Atlantic. Check List 8(3): 528-530.

Silva AG, Paula AF, Fleury BG, Creed JC (2014) Eleven years of range expansion of two invasive corals (Tubastraea coccinea and Tubastraea tagusensis) through the southwest Atlantic (Brazil). Estuarine, Coastal and Shelf Science 141: 9-16. doi: 10.1016/j.ecss.2014.01.013

Tilbrook KJ (2006) Cheilostomatous Bryozoa from the Solomon Islands. Santa Barbara Museum of Natural History Monographs 4: 1-385.

Tilвrook KJ, Gordon DP (2015) Bryozoa from the Straits of Johor, Singapore, with the description of a new species. Raffles Bulletin of Zoology (Suppl. 31): 255-263.

Tyrell MC, Byers JE (2007) Do artificial substrates favor nonindigenous fouling species over native species? Journal of Experimental Marine Biology and Ecology 342: 54-60. doi: 10.1016/j.jembe.2006.10.014

Vieira LM, Migotto AM (2014) Membraniporopsis tubigera (Osburn, 1940) (Bryozoa) on floating substrata: evidence of a dispersal mechanism. Marine Biodiversity 45: 155-156. doi: 10.1007/s12526-014-0260-1

Vieira LM, Migotto AE, Winston JE (2008) Synopsis and annotated checklist of recent marine Bryozoa from Brazil. Zootaxa 1810: 1-39.

Vieira LM, Gordon DP, Souza FBC, Haddad MA (2010) New and little-known cheilostomatous Bryozoa from the south and southeastern Brazilian continental shelf and slope. Zootaxa 2722: $1-30$.

Submitted: 17 July 2015

Received in revised form: 11 August 2015

Accepted: 29 August 2015

Editorial responsibility: Rosana M. da Rocha
Vieira LM, Spencer Jones M, Winston JE (2013) Resurrection of the genus Licornia for Scrupocellaria jolloisii (Bryozoa) and related species, with documentation of $L$. jolloisii as a nonindigenous species in the western Atlantic. Journal of the Marine Biological Association of the United Kingdom 93(7): 1911-1921. doi: 10.1017/S0025315413000301

Vieira LM, Spencer Jones M, Winston JE (2014) The identity of the invasive fouling bryozoan Watersipora subtorquata (d'Orbigny) and some other congeneric species. Zootaxa 3857: 151-182. doi: 10.11646/zootaxa.3857.2.1

Wanninger A, Koop D, Degnan BM. 2005. Immunocytochemistry and metamorphic fate of the larval nervous system of Triphyllozoon mucronatum (Ectoprocta: Gymnolaemata: Cheilostomata). Zoomorphology 124: 161-170. doi: 10.1007/s00435-005-0004-7

Waeschenbach A, Vieira LM, Reverter-Gil O, Souto-Derungs J, Nascimento KB, Fehlauer-Ale KH. 2015. A phylogeny of Vesiculariidae (Bryozoa, Ctenostomata) supports synonymisation of three genera and reveals possible cryptic diversity. Zoologica Scripta. doi: $10.1111 / z s c .12130$

WatTS PC, ThorPe JP, TAYLor PD (1998) Natural and anthropogenic dispersal mechanisms in the marine environment: a study using cheilostome Bryozoa. Philosophical Transactions of the Royal Society B: Biological Sciences 353 (1367): 453464.

Winston JE (1986) An annotated check-list of coral-associated bryozoans. American Museum Novitates 2859: 1-39.

Winston JE, Vieira LM (2013) Systematics of interstitial encrusting bryozoans from southeastern Brazil. Zootaxa 3710: 101-146. doi: 10.11646/zootaxa.3710.2.1

Winston JE, Vieira LM, Woollacott RM (2014) Scientific results of the Hassler Expedition. Bryozoa. No. 2. Brazil. Bulletin of the Museum of Comparative Zoology at Harvard College 161(5): 139-239. doi: 10.3099/MCZ14.1 